\title{
Combination of temozolomide with immunocytokine FI6-IL2 for the treatment of glioblastoma
}

\author{
M Pedretti', C Verpelli', J Mårlind', G Bertani ${ }^{3}$, C Sala ${ }^{2}$, D Neri*, and L Bello ${ }^{3}$ \\ 'Institute of Pharmaceutical Sciences, Department of Chemistry and Applied Biosciences, ETH-Swiss Federal Institute of Technology Zurich, Wolfgang- \\ Pauli-Strasse 10, 8093 Zurich, Switzerland; ${ }^{2}$ Institute of Neurosciences, CNR, Via Vanvitelli 32, 20129 Milan, Italy; ${ }^{3}$ Department of Neurological Sciences, \\ University of Milan, IRCCS Ospedale Maggiore, Via Francesco Sforza 35, 20122 Milan, Italy
}

BACKGROUND: Glioblastoma patients are still not cured by the treatments available at the moment. We investigated the therapeutic properties of temozolomide in combination with $\mathrm{Fl6}-\mathrm{IL} 2$, a clinical-stage immunocytokine consisting of human interleukin (IL)-2 fused to the human antibody FI6, specific to the Al domain of tenascin-C.

METHODS: We conducted three preclinical therapy studies, using subcutaneous and intracranial U87MG glioblastoma tumours xenografted in BALB/c nude mice. The same therapeutic schedule was used, consisting of five total administrations every third day, of $0.525 \mathrm{mg}$ temozolomide, $20 \mu \mathrm{g}$ Fl6-IL2, the combination, or the control solution.

RESULTS: Immunohistochemical analysis of U87MG xenografts and of human glioblastoma specimens showed selective tumour staining of FI6. A quantitative biodistribution confirmed the preferential tumour accumulation of radiolabelled FI6-IL2. In the study with subcutaneous xenografts, the combination of FI6-IL2 with temozolomide induced complete remission of the animals, which remained tumour free for over 160 days. The same treatment led to a consistent size reduction of intracranial xenografts and to a longer survival of animals. The immunocytokine promoted the recruitment of leukocytes into tumours of both models.

CONCLUSION: The combined use of temozolomide with FI6-IL2 deserves clinical investigations, which will be facilitated by the excellent safety profile in cynomolgus monkeys, and by the fact that FI6-IL2 is in clinical trials in patients with cancer.

British Journal of Cancer (2010) 1 03, 827-836. doi:10.1038/sj.bjc.6605832 www.bjcancer.com

Published online 24 August 2010

(C) 2010 Cancer Research UK

Keywords: glioblastoma; AI domain of tenascin-C; interleukin-2; immunocytokines; temozolomide

Central nervous system tumours rank first among neoplasia types for the average years of life lost (Burnet et al, 2005). Approximately 13000 deaths and 18000 new cases of central nervous system tumours occur annually in the United States (CBTRUS Statistical report, 2006). Mortality rates are generally similar to incidence rates in most geographical areas (Ferlay et al, 2000).

The term 'glioma' refers to tumours of glial cell origin and includes astrocytomas, oligodendrogliomas, ependimomas, and mixed gliomas (Kleihues and Cavenee, 2000). They account for more than $70 \%$ of all brain tumours and their prognosis is very poor. Glioblastoma is the most frequent ( $65 \%$ of all gliomas) and also the most malignant histological type (Ohgaki et al, 2004).

The prognosis of glioblastoma continues to be dismal in spite of progress made in the molecular characterisation of the most frequent genetic alterations of the disease (Parsons et al, 2008). Even state-of-the art multimodality treatments, although capable of substantially extending life expectancy, are not curative (Stupp et al, 2005). The current standard of care for patients with glioblastoma includes surgery, radiotherapy, and concurrent and adjuvant temozolomide (Stupp et al, 2005). Temozolomide is an oral alkylating drug that has demonstrated antitumour activity as a single agent in the treatment of recurrent glioma (Newlands et al,

*Correspondence: Dr D Neri; E-mail: neri@pharma.ethz.ch Received 2 July 2010; revised 6 July 20I0; accepted 12 July 2010; published online 24 August 2010
1997; Yung et al, 2000; Stupp et al, 2001). Temozolomide is indicated for newly diagnosed glioblastoma patients in association with radiotherapy in the postsurgical period $\left(75 \mathrm{mg} \mathrm{m}^{-2}\right.$ p.o. daily for 6 weeks, during a focal radiotherapy taking place five times a week for 6 weeks, for a total dose of $60 \mathrm{~Gy}$ ), and alone during the maintenance period $\left(150-200 \mathrm{mg} \mathrm{m}^{-2}\right.$ p.o. on days $1-5$, every 28 days for six cycles). Nevertheless, this treatment modality yields a median survival benefit of 2.5 months, compared with adjuvant radiotherapy alone (Stupp et al, 2005).

Conventional cytotoxic therapies of cancer often do not discriminate between tumour and normal tissues. To achieve therapeutically relevant concentrations in the tumour mass, large drug doses have to be administered to the patient, leading to a poor therapeutic index and unacceptable toxicities to healthy tissues (Bosslet et al, 1998). The selective delivery of therapeutic agents to the tumour site, using antibodies directed against tumour-associated antigens, represents a promising strategy to overcome the disadvantages of conventional cancer therapies (Adams and Weiner, 2005; Carter, 2006; Schrama et al, 2006). Antigens that are expressed around the tumour neovasculature are especially attractive targets for antibody-based pharmacodelivery applications because of their inherent accessibility for blood-borne agents and because angiogenesis is a characteristic feature of virtually all aggressive solid tumours (Thorpe, 2004; Neri and Bicknell, 2005; Schliemann and Neri, 2007). Our group has demonstrated the possibility of delivering bioactive agents to the 
subendothelial extracellular matrix using monoclonal antibodies specific to splice isoforms of fibronectin and tenascin-C (Birchler et al, 1999; Carnemolla et al, 2002; Halin et al, 2002, 2003; Borsi et al, 2003; Ebbinghaus et al, 2005; Neri and Bicknell, 2005; Tijink et al, 2006; Kaspar et al, 2007). In particular, encouraging results obtained with derivatives of the human monoclonal antibodies L19 (specific to the extradomain B of fibronectin) and F16 (specific to the extradomain A1 of tenascin-C) have led to the clinical development of five immunocytokines and radioimmunoconjugates (Carnemolla et al, 2002; Halin et al, 2002, 2003; Borsi et al, 2003; Ebbinghaus et al, 2005; Menrad and Menssen, 2005; Schliemann and Neri, 2007; Mårlind et al, 2008).

Microvascular proliferation is a characteristic feature of glioblastoma (Kleihues and Cavenee, 2000; Castellani et al, 2002). An overexpression of the extradomain B of fibronectin in highgrade gliomas has been established and the monoclonal antibody L19 has been shown to target glioblastoma in patients (Castellani et al, 1994, 2002; Santimaria et al, 2003). Furthermore, radiolabelled preparations of monoclonal antibodies specific to the A1 or the $\mathrm{D}$ domain of tenascin-C have been investigated for the radioimmunotherapy of patients with glioblastoma (Riva et al, 2000; Paganelli et al, 2006; Zalutsky et al, 2007, 2008).

In this study, we have explored the possibility of using immunocytokine F16-IL2 in combination with temozolomide for the therapy of experimental murine models of glioblastoma. F16-IL2 is a noncovalent homodimeric immunocytokine consisting of the human proinflammatory cytokine interleukin (IL)-2 fused to the human antibody fragment scFv(F16). Both F16 and F16-IL2 have been shown to intensely stain aggressive cancer types and to preferentially accumulate at the tumour site following intravenous administration (Brack et al, 2006; Mårlind et al, 2008). F16-IL2 has recently been shown to mediate an anticancer effect, which can be potentiated by coadministration of taxanes or adriamycins, leading to the initiation of two phase Ib clinical studies in patients with metastatic breast or ovarian cancer (F16-IL2 + doxorubicin), or breast or lung cancer (F16-IL2 + paclitaxel). Tumour-targeting immunocytokines based on IL2 have previously been demonstrated to mediate the infiltration of immune cells into the tumour mass, with natural killer (NK) cells as the main mediator of therapeutic activity (Reisfeld and Gillies, 1996; Carnemolla et al, 2002; Mårlind et al, 2008; Schliemann et al, 2009). These properties may be beneficial in the context of glioblastoma therapy (Dunne et al, 2001; Albertsson et al, 2003). In our experiments, F16-IL2 was found to potentiate the therapeutic action of temozolomide in nude mice bearing subcutaneous and orthotopic human glioblastoma xenografts.

\section{MATERIALS AND METHODS}

\section{Cell lines and animals}

Human subcutaneous and orthotopic glioblastoma xenografts were obtained by injection of U87MG human glioblastoma cells (ATCC Nr: HTB-14). This cell line was cultured in MEM (Invitrogen, Basel, Switzerland), supplemented with $10 \%$ fetal calf serum (Invitrogen), $2 \mathrm{~mm}$ L-glutamine, $1 \mathrm{~mm}$ sodium pyruvate, and $100 \mathrm{U} \mathrm{mL}^{-1}$ ampicillin, and incubated at $37^{\circ} \mathrm{C}$ in $5 \% \mathrm{CO}_{2}$. Animal experiments with subcutaneous glioblastoma xenografts were conducted in female BALB/c nude mice (Charles River Laboratories, Sulzfeld, Germany) under a project licence granted by the Veterinäramt des Kantons Zürich (198/2005), whereas orthotopic glioblastoma therapy experiments were conducted in male $\mathrm{BALB} / \mathrm{c}$ nude mice (Charles River Laboratories), according to the University of Milan animal facility rules.

\section{Antibodies and therapeutic agents}

The L19 antibody, specific to the extradomain B of fibronectin, the F16 antibody, specific to the extradomain A1 of tenascin-C, and the preparation and characterisation of the F16-IL2 fusion protein with human interleukin-2 have been described before (Pini et al, 1998; Neri and Bicknell, 2005; Brack et al, 2006; Mårlind et al, 2008) Temozolomide (ABCR GmbH \& Co. KG, Karlsruhe, Germany) was dissolved in a saline solution $\left(\mathrm{H}_{2} \mathrm{O} \quad 0.9 \% \mathrm{NaCl}\right)$ containing $10 \%$ dimethyl sulfoxide (DMSO).

\section{Immunohistochemistry on human glioblastoma samples and glioblastoma xenografts}

Surgically resected human glioblastoma tissues and U87MG subcutaneously xenografted glioblastomas were freshly frozen in OCT (optimal cryotemperature) medium as described (Borsi et al, 2002; Castellani et al, 2002) and stored at $-80^{\circ} \mathrm{C}$ before being processed.

For immunohistochemical procedures, F16 and L19 antibodies were used in biotinylated small immunoprotein (SIP) format (Borsi et al, 2002; Brack et al, 2006). Aliquots of antibodies were prepared from a single batch, stored at $4^{\circ} \mathrm{C}$, and used only once, thus contributing to excellent reproducibility of immunohistochemical results.

Tissue sections of $10 \mu \mathrm{m}$ thickness were treated with ice-cold acetone, rehydrated in Tris buffer solution $(50 \mathrm{~mm}$ Tris, $100 \mathrm{~mm}$ $\mathrm{NaCl}, 0.001 \%$ Aprotinin, $\mathrm{pH} 7.4$ ), and blocked with Tris buffer solution $20 \%$ fetal calf serum. Biotinylated SIP(F16) and SIP(L19) were added onto the sections in a final concentration of $2 \mu \mathrm{g} \mathrm{ml}^{-1}$ and detected using a streptavidin-alkaline phosphatase complex (Biospa, Milano, Italy) as described (Borsi et al, 2002; Castellani et al, 2002). Fast Red (Tablets Set, Sigma-Aldrich Chemie GmbH, Steinheim, Germany) was used as phosphatase substrate and sections were counterstained with Gill's haematoxylin no. 2 (Sigma-Aldrich Chemie $\mathrm{GmbH}$ ). For every immunohistochemical experiment, a negative control was used by omitting the primary antibody.

The optic microscope Zeiss Axiovert S100TV (Carl Zeiss MicroImaging $\mathrm{GmbH}$, Jena, Germany), at $5 \times, 10 \times$, and $20 \times$ magnifications, and the Zeiss Axiovision Release 4 acquisition software were used to evaluate the expression of the $\mathrm{A} 1$ domain of tenascin- $\mathrm{C}$ and the extradomain $\mathrm{B}$ of fibronectin, as revealed by staining using F16 and L19 antibodies, respectively.

\section{Biodistribution experiment}

The in vivo targeting performance of F16-IL2 was evaluated by quantitative biodistribution analysis (Carnemolla et al, 2002). Female BALB/c nude mice bearing subcutaneous U87MG tumours (obtained by a s.c. flank injection of $5 \times 10^{6}$ U87 cells) were grouped ( $n=5$ /group) when tumours were clearly palpable (volume of ca $200 \mathrm{~mm}^{3}$ ) and injected i.v. into the lateral tail vein with radioiodinated F16-IL2. Antibody immunoreactivity after labelling was evaluated by loading a sample of radiolabelled F16-IL2 onto TNC-A1-Sepharose resin, followed by radioactive counting of the flow-through and eluate fractions. Immunoreactivity, defined as the ratio between the counts of the eluted protein and the sum of the counts of the eluted and flow-through fractions, was $84 \%$. Mice were killed $24 \mathrm{~h}$ after injection of F16-IL2 $(10 \mu \mathrm{g}$, $3.6 \mu \mathrm{Ci}$ per mouse), organs were weighed, and radioactivity was counted with a Packard Cobra gamma counter (GMI Inc, Ramsey, $\mathrm{MN}, \mathrm{USA}$ ). The radioactivity content of representative organs was expressed as the percentage of the injected dose per gram of tissue $\left(\% \mathrm{ID} \mathrm{g}^{-1}\right)$.

\section{Subcutaneous glioblastoma mouse model}

Subcutaneous glioblastoma-bearing mice were obtained by a s.c. flank injection of $5 \times 10^{6}$ U87MG cells in 8 -week-old female BALB/c nude mice. Twelve days after tumour cell implantation, when tumours had reached an average size of $300 \mathrm{~mm}^{3}$, mice were staged 
to maximise uniformity among the groups ( $n=5 /$ group). One group was injected i.v. (lateral tail vein) with $20 \mu \mathrm{g}$ of F16-IL2 (corresponding to $6.6 \mu \mathrm{g}$ of IL-2) in a total volume of $100 \mu \mathrm{l}$ PBS (phosphate-buffered saline) solution, one was injected i.p. with $0.525 \mathrm{mg}$ of temozolomide (corresponding to $75 \mathrm{mg} \mathrm{m}^{-2}$ ) in a total volume of $150 \mu \mathrm{l}$ saline $10 \%$ DMSO, a third group received both the i.v. injection of $20 \mu \mathrm{g}$ F16-IL2 and the i.p. of $0.525 \mathrm{mg}$ temozolomide. Finally, the control group was injected i.p. with $150 \mu \mathrm{l}$ of saline $10 \%$ DMSO. Five total administrations were performed on days $12,15,18,21$, and 24 . Using a conversion factor based on body surface (Reagan-Shaw et al, 2008), the dose of temozolomide used in this study corresponded to a human dose of $75 \mathrm{mg} \mathrm{m}^{-2}$ for each injection (Stupp et al, 2005). The cumulative dose of temozolomide per mouse was lower than the $\mathrm{LD}_{10}$ (dose lethal to $10 \%$ of treated animals) for both subcutaneous and orthotopic glioblastoma mouse models (Friedman et al, 2000).

Animals were monitored and weighted daily; tumours were measured with a digital caliper three times a week. Tumour volume was estimated using the formula volume $=$ length $\times$ width $^{2} / 2$. Mice were killed when tumours approached a volume of $3000 \mathrm{~mm}^{3}$ or when tumours turned necrotic and bled, according to Swiss regulations. No animals had to be killed because of therapyderived toxicities.

\section{Orthotopic glioblastoma mouse model}

Orthotopic glioblastoma-bearing mice were obtained by an intracranial implantation of $5 \times 10^{4}$ U87MG cells in 6-week-old male BALB/c nude mice (Bello et al, 2004). Twelve days after tumour cell implantation, mice were randomly divided into four therapeutic groups ( $n=10$ /group). Schedule and doses of therapeutics were the same as for the therapy with subcutaneous glioblastoma-bearing mice.

Mice were monitored daily to detect any signs of neurological suffering from tumour growth or from toxicity effects of the therapy. All therapeutic groups were killed 25 days after therapy beginning. Brains were removed and the hemisphere containing the tumour and the contralateral one were separately snap-frozen and stored at $-80^{\circ} \mathrm{C}$. Tumours were measured by thawing the corresponding hemisphere and by sectioning the tissue when necessary. Tumour volume was estimated using the formula volume $=$ length $\times$ width $^{2} / 2$. The healthy hemisphere was taken as control.

We repeated the therapy with intracranial U87MG xenografted mice, comparing the four therapeutic groups on a survival basis. Orthotopic glioblastoma-bearing mice were obtained by an intracranial implantation of $5 \times 10^{4}$ U87MG cells in 6-weekold male BALB/c nude mice (Bello et al, 2004). Twelve days after tumour cell implantation, mice were randomly divided into four therapeutic groups $(n=8$ /group and $n=9$ for the temozolomide + F16-IL2 combination group). Schedule and doses of therapeutics were the same as for the previous therapies. Mice were monitored daily and killed at the first appearance of neurological damage from tumour growth or on detection of any signs of suffering from therapy-related toxicity. Kaplan-Meier survival curves were drawn.

\section{Assessment of immune effector cell infiltration in subcutaneous and intracranial glioblastoma xenografts, and in normal organs following treatment}

To evaluate the role of inflammatory cell responses, BALB/c nude mice bearing s.c. or i.c. U87MG tumours ( $n=3 /$ therapeutic group) were treated on days 12,15 , and 18 after tumour cell implantation with F16-IL2 (i.v.), temozolomide (i.p.), F16-IL2 (i.v.) plus temozolomide (i.p.), or saline $10 \%$ DMSO solution (i.p.). Mice were killed $24 \mathrm{~h}$ after the third injection. Tumours were excised and snap-frozen in OCT medium, and liver and kidneys were fixated in $4 \%$ formalin and embedded in paraffin according to standard procedures.

The immunofluorescent staining of subcutaneous and intracranial tumour sections was performed using antibodies against the following antigens: F4/80 (rat antimouse F4/80, clone A3-1, AbCam, Cambridge, UK) for the detection of tumour-infiltrating macrophages, asialo GM1 (rabbit antiasialo GM1, Wako Pure Chemical Industries Ltd, Osaka, Japan) for NK cells, and CD45 (rat antimouse CD45, BD Biosciences Pharmingen, Allschwil, Switzerland) for leukocytes. In all cases, CD31 staining (rabbit or rat antimouse CD31, BD Biosciences Pharmingen) was performed to identify vascular structures.

Frozen tumour sections of $10 \mu \mathrm{m}$ thickness were treated with ice-cold acetone, blocked with PBS $10 \%$ donkey serum $+10 \%$ goat serum, incubated with primary antibodies (in a PBS $12 \%$ bovine serum albumin (BSA) solution), and detected using fluorescent Alexa 488- or Alexa 594-coupled secondary antibodies (donkey antirat or goat antirabbit IgG, BD Biosciences Pharmingen) in a PBS 12\% BSA solution. The microscope Zeiss Axioskop 2 mot plus with the fluorescence lamp HXP 120 Kubler Codix (Carl Zeiss MicroImaging $\mathrm{GmbH}$ ), and the acquisition software Zeiss Axiovision Release 4 were used for analysis.

Paraffin-embedded liver and kidney sections from mice of the different therapeutic groups were baked overnight at $60^{\circ} \mathrm{C}$ and deparaffinised according to standard procedures. Antigen retrieval was obtained by microwave warming in $8.2 \%$ trisodium citrate $(0.1 \mathrm{M})+1.8 \%$ Citric Acid $(0.1 \mathrm{M})$ solution. Sections were blocked with PBSTT (PBS 0.5\% Tween $+0.1 \%$ Triton-X) 10\% BSA, incubated first with the primary antibody rat antimouse CD45 (clone 30-F11, BD Biosciences Pharmingen), then with the secondary antibody biotinylated mouse antirat $\operatorname{IgG}_{2}$ (clone G15337, BD Biosciences Pharmingen), followed by Streptavidin Alexa 488-coupled + 4'-6-diamidino-2-phenylindole. Glioblastoma tumours from the same mice were used as positive control.

In each tissue section, staining was quantified in three representative microscopic images using Image J software (http://rsb.info.nih. gov/ij/) and expressed as a percentage of measurement area.

\section{Ex vivo detection of the F16-IL2 fusion protein in subcutaneous and intracranial glioblastoma xenografts following treatment}

The in vivo localisation of the F16-IL2 fusion protein within the tumour mass was investigated in subcutaneous and intracranial glioblastoma xenografts collected from BALB/c nude mice $(n=3$ / therapeutic group), which were treated on days 12,15 , and 18 (day $0=$ tumour cell implantation) with F16-IL2 or with the combination of F16-IL2 and temozolomide, and killed $24 \mathrm{~h}$ after the third drug administration.

A rat antihuman IL-2 antibody (eBioscience Inc., San Diego, CA, USA) was used to detect the F16-IL2 fusion protein within the tumour mass, and the CD31 staining (rabbit anti-mouse CD31, BD Biosciences Pharmingen) served to identify vascular structures. Immunofluorescent staining and analysis of results were performed in the same way as for the immune cell infiltration study.

The specific binding of the rat antihuman IL-2 antibody to the F16-IL2 immunocytokine was validated by enzyme-linked immunosorbent assay. We loaded the biotinylated tenascin-C A1 antigen $\left(10^{-6} \mathrm{M}\right)$ on streptavidin wells $(\mathrm{A}-\mathrm{H})$, followed by $5 \mu \mathrm{g} \mathrm{ml}^{-1}$ of F16-IL2 in PBS $2 \%$ milk in wells A-C, and $5 \mu \mathrm{g} \mathrm{ml}^{-1}$ of F8-IL2 in wells D-F as irrelevant antibody; wells G-H served as negative control without primary antibody. The rat antihuman IL-2 antibody (eBioscience Inc; diluted $1: 1000$ ) was used as secondary antibody (wells $\mathrm{A}-\mathrm{H}$ ), followed by the goat antirat IgG-HRP (eBioscience Inc.; diluted $1: 1000$ ), the POD substrate (Roche Diagnostic, Rotkreuz, Switzerland), and the $\mathrm{H}_{2} \mathrm{SO}_{4} 1 \mathrm{M}$ solution to complete the reaction. 


\section{Assessment of apoptosis and proliferation in subcutaneous glioblastoma xenografts following treatment}

The analysis of apoptosis and proliferation induced by the therapy was performed in subcutaneous glioblastoma xenografts collected from $\mathrm{BALB} / \mathrm{c}$ nude mice ( $n=3 /$ therapeutic group), which were treated on days 12,15 , and 18 (day $0=$ tumour cell implantation) with F16-IL2, temozolomide, the combination of F16-IL2 and temozolomide, or saline $10 \%$ DMSO solution, and killed $24 \mathrm{~h}$ after the third drug administration.

Fluorescent TUNEL (Terminal deoxynucleotidyl transferase dUTP nick end labeling) assays (Roche Diagnostic) were performed according to the manufacturer's instructions to detect apoptosis in tumours of the different therapeutic groups.

The same specimens were analysed by immunofluorescence to detect proliferation as revealed by the Ki67 antigen. Tumour sections were blocked first with PBS $10 \%$ donkey serum $+10 \%$ goat serum, then with AffiniPure Fab fragment goat antimouse IgG (Jackson ImmunoResearch Laboratories Inc., West Grove, PA, USA) in a PBS $12 \%$ BSA solution. A monoclonal mouse antihuman Ki67 (clone B126.1, AbCam) and a rat antimouse CD31 (BD Biosciences Pharmingen) were used as primary antibodies, followed by Alexa 594-coupled donkey antirat IgG and Alexa 488-coupled goat antimouse IgG (BD Biosciences Pharmingen) + 4'-6-diamidino-2phenylindole in a PBS $12 \%$ BSA solution. The analysis and quantification of results were performed in the same manner as for the previous immunofluorescence experiments.

\section{Statistics}

Comparisons of data of the efficacy study with intracranial xenografts and of the infiltration and apoptosis/proliferation

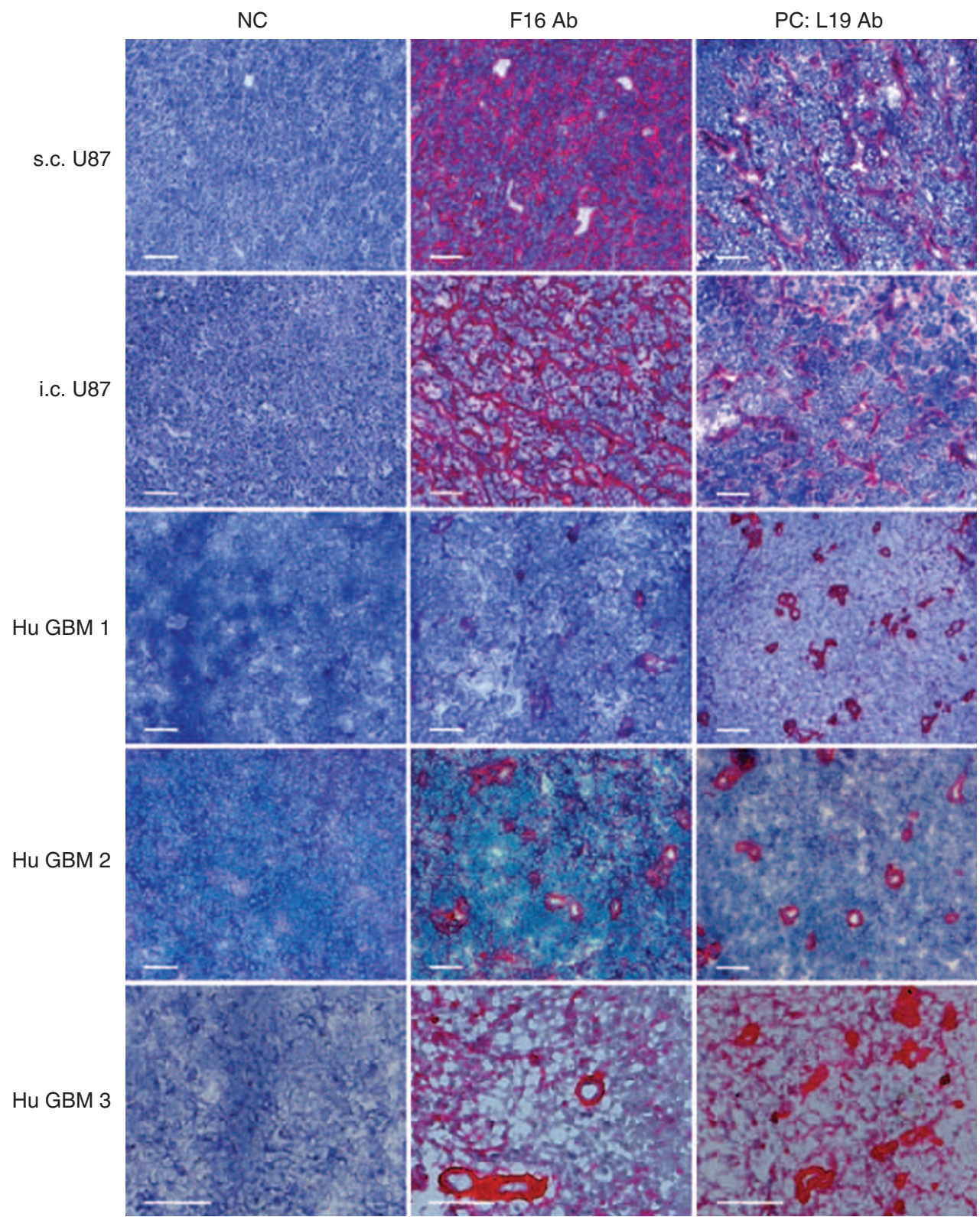

Figure I Immunohistochemical analysis of U87MG human glioblastoma xenografts and of human glioblastoma surgical specimens using the FI6 antibody, specific to the extradomain AI of tenascin-C, and the LI9 antibody, specific to the extradomain B of fibronectin (serial tissue sections). Both antibodies stained tumour perivascular structures considerably. In negative controls (NC), the primary antibody was omitted. Scale bars indicate $100 \mu$ m. 
studies were performed using a two-tailed Student's $t$-test. Survival analysis was conducted by Kaplan-Meier curves, and their comparison was determined by log-rank test. $P$-values of $<0.05$ were considered significant.

\section{RESULTS}

Immunohistochemistry on human glioblastoma specimens and on mouse U87MG xenografts

We assessed the expression of the A1 domain of tenascin- $\mathrm{C}$ and of the extradomain B of fibronectin (as positive control) in sections of human glioblastoma surgical specimens and of U87MG xenografts in nude mice. We used identical concentrations of F16 and L19 antibodies (Pedretti et al, 2009). F16 was found to strongly stain both experimental U87MG tumours and glioblastoma samples from patients, with patterns and intensities comparable to the ones of L19 (Figure 1), which had previously been reported to stain perivascular structures in high-grade gliomas (Castellani et al, 2002).

\section{Biodistribution study with radiolabelled F16 - IL2}

Nude mice bearing subcutaneous U87MG glioblastomas were injected i.v. with radioiodinated preparations of F16-IL2 to study the in vivo targeting performance by quantitative biodistribution analysis. The immunocytokine displayed a preferential accumulation in the tumour $24 \mathrm{~h}$ after injection $\left(2.3 \% \mathrm{ID} \mathrm{g}^{-1}\right)$, with a tumourto-blood ratio of 11.5 and with excellent tumour-to-organ ratios (Supplementary Figure 1). In our previous experience, normal brain and muscle exhibited uptake levels at least 10 times lower than that of other organs (Berndorff et al, 2006; Spaeth et al, 2006).

\section{Therapeutic activity of F16-IL2 combined with temozolomide in subcutaneous and intracranial glioblastoma xenografts}

We compared the therapeutic activity of F16-IL2 and of temozolomide (alone and in combination) in nude mice bearing subcutaneous U87MG tumours. Therapy was started 12 days after subcutaneous injection of U87MG cells, when tumours had reached an average size of $300 \mathrm{~mm}^{3}$. Temozolomide was administered five times, every third day, with i.p. injections of $0.525 \mathrm{mg}$ in saline $10 \%$ DMSO. This dose is higher than the one used in previous therapy studies with the same agent (Chakravarti et al, 2006; Yamini et al, 2007), but is well below the $\mathrm{LD}_{10}$ of temozolomide in nude mice, reported to be equal to $411 \mathrm{mg} \mathrm{m}^{-2}$ administered i.p. daily for 5 days, and to $1200 \mathrm{mg} \mathrm{m}^{-2}$ administered i.p. once (Friedman et al, 2000). The dose of temozolomide used in this study corresponds to a human dose of $75 \mathrm{mg} \mathrm{m}^{-2}$ for each injection, in line with the standard $75 \mathrm{mg} \mathrm{m}^{-2}$ p.o. daily dose of temozolomide, administered to patients for 6 weeks during adjuvant radiation therapy (Stupp et al, 2005; Reagan-Shaw et al, 2008). F16-IL2 was administered i.v. at $20 \mu \mathrm{g}$ doses (corresponding to $6.6 \mu \mathrm{g}$ of IL2).

Monotherapy treatment with F16-IL2 led to a minor tumour growth retardation, compared with the control group of mice treated with saline $10 \%$ DMSO, whereas all mice in the temozolomide group exhibited a strong tumour regression by day 30 (Figure 2A). However, by day 45, tumours started to grow again in three out of five mice. By contrast, mice treated with the combination of F16-IL2 plus temozolomide exhibited a complete remission and remained tumour free for over 160 days.

The toxicity of pharmacological treatments in tumour-bearing mice is commonly evaluated by a constant monitoring of weight loss. In this study, mice of the control group did not exhibit weight loss, whereas mice of the temozolomide, F16-IL2, and F16-IL2
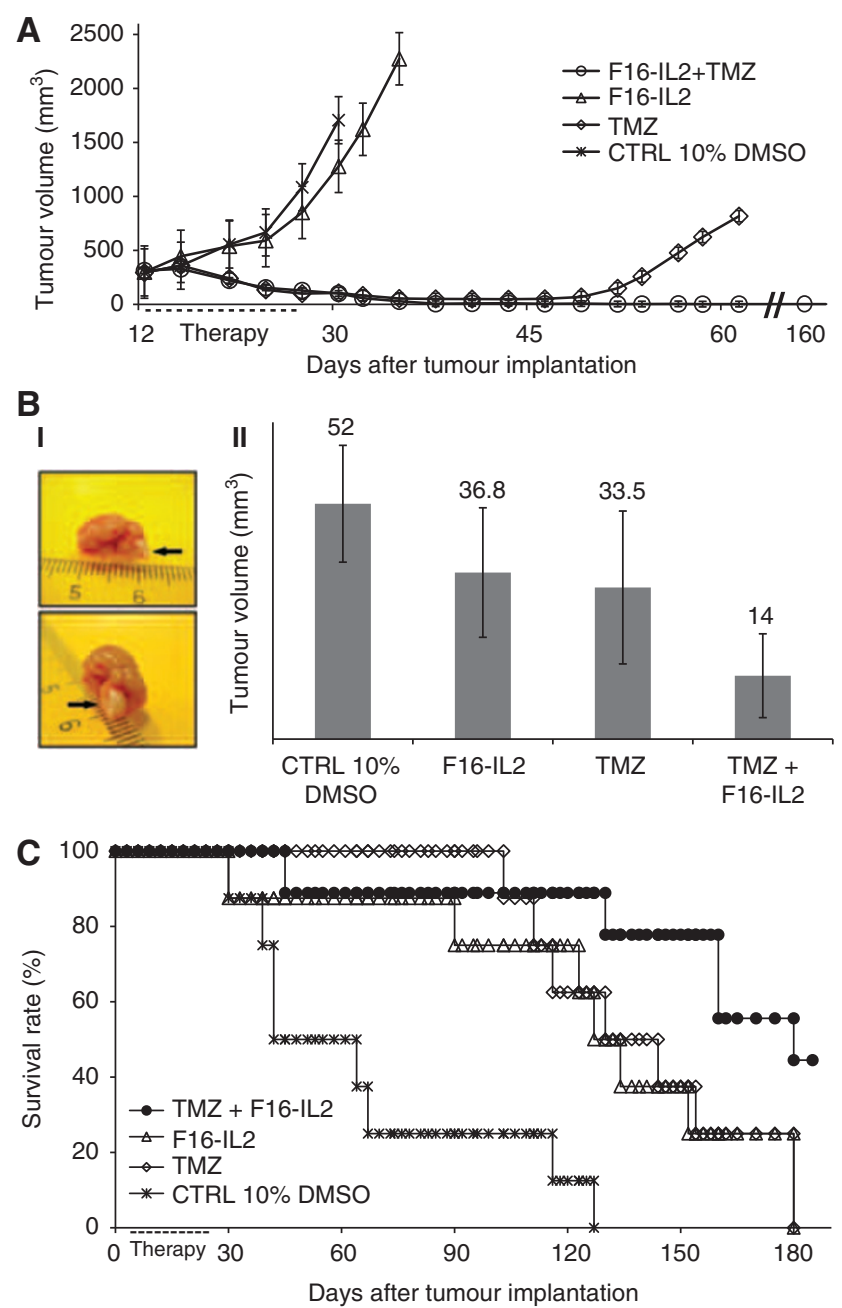

Figure 2 (A) Preclinical therapy study with subcutaneous U87MG human glioblastoma xenografts. The treatment regimen consisted of five total administrations, every third day, of temozolomide $0.525 \mathrm{mg}$, corresponding to $75 \mathrm{mg} \mathrm{m}^{-2}$ ) in a saline $10 \%$ dimethyl sulfoxide (DMSO) solution, $\mathrm{Fl} 6-\mathrm{IL} 2(20 \mu \mathrm{g})$ in phosphate-buffered saline, a combination of FI6-IL2 and temozolomide (same doses), or saline I0\% DMSO solution. The combination therapy group exhibited the highest therapeutic benefit with a complete remission of the animals, which remained tumour free for over 160 days. (B) Preclinical therapy study, using intracranial U87MG human glioblastoma xenografts. The same therapeutic schedule of the subcutaneous study was used. The combination of FI6-IL2 with temozolomide exhibited the highest therapeutic benefit. Pairwise comparisons between the combination therapy group and temozolomide alone $(P=0.009), F I 6-I L 2$ alone $(P=0.00 I)$, and the control group $(P<0.00 I)$ were calculated using the Student's $t$-test and showed significant results. (I) Photograph of a mouse hemisphere with tumour, imaged from two sides. (II) Tumour volumes at day 25 from the start of treatment ( 13 days after the last drug administration), expressed as average mean \pm s.d. (C) Survival study using intracranial U87MG human glioblastoma xenografts, with the same therapeutic schedule of the previous subcutaneous and intracranial studies. Results indicate a longer survival for the combination treatment group (combo vs TMZ: $P<0.002$; combo vs FI6-IL2: $P<0.002$; combo vs control: $P<0.000$ I).

plus temozolomide treatment groups exhibited a comparable profile of weight loss, which was at all time points below $9 \%$ (Supplementary Figure 2A).

Encouraged by the tumour eradication obtained in subcutaneous xenografts, we studied the therapeutic performance of F16-IL2 and temozolomide in an intracranial model of glioblastoma, obtained by stereotactic injection of $5 \times 10^{4}$ U87MG cells into nude mice. The treatment schedule and doses were as for the 
A

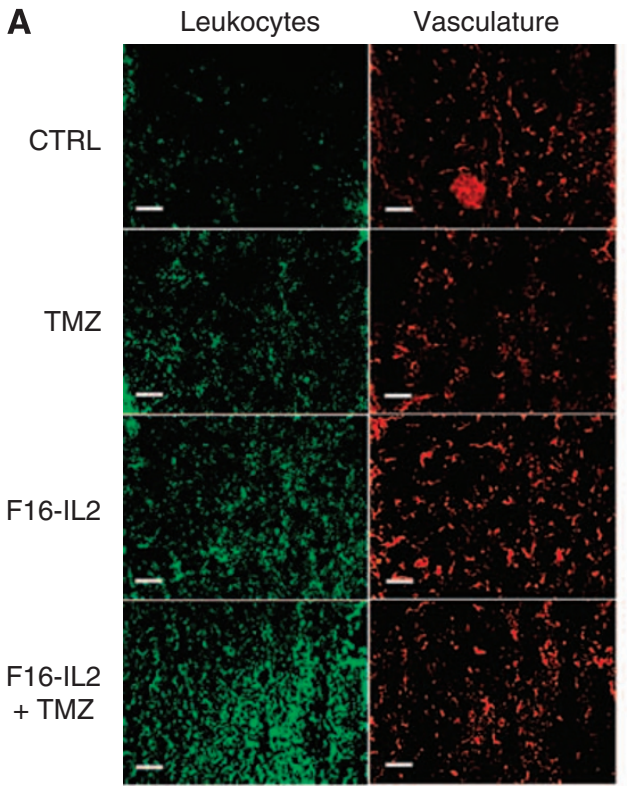

B

CTRL

TMZ

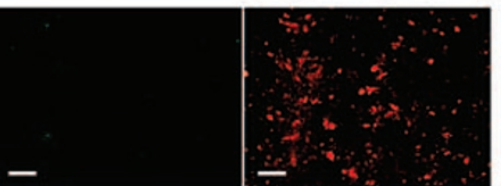

F16-IL2

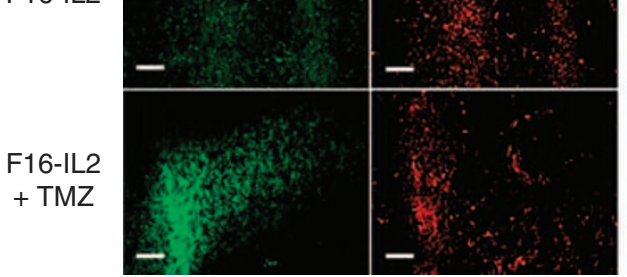

NK cells
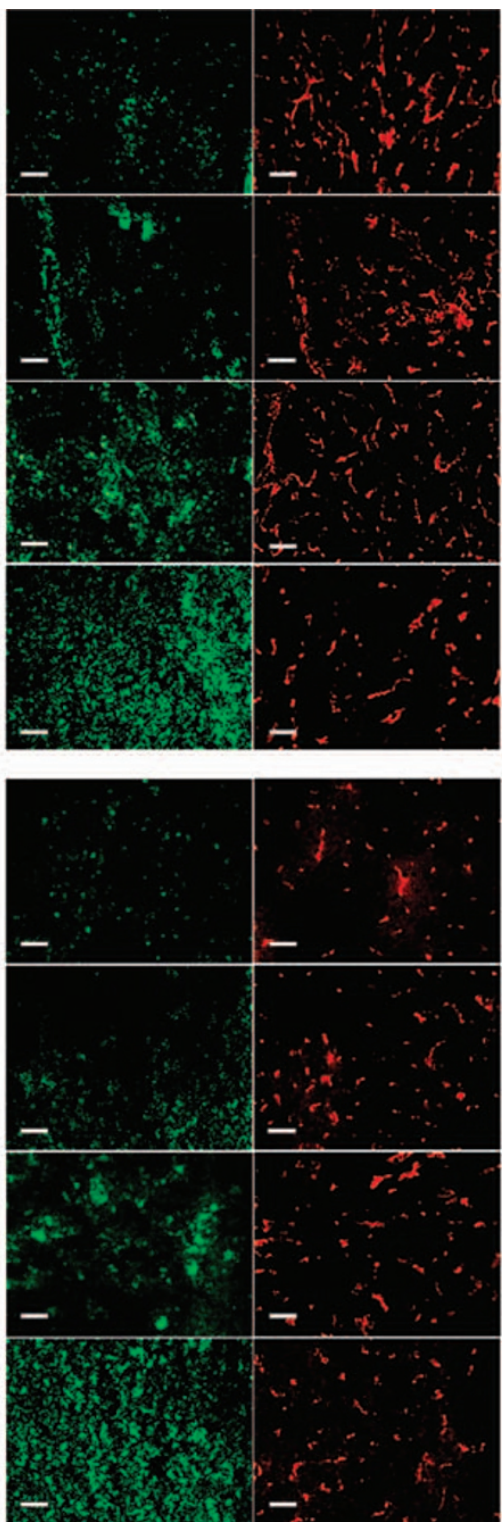
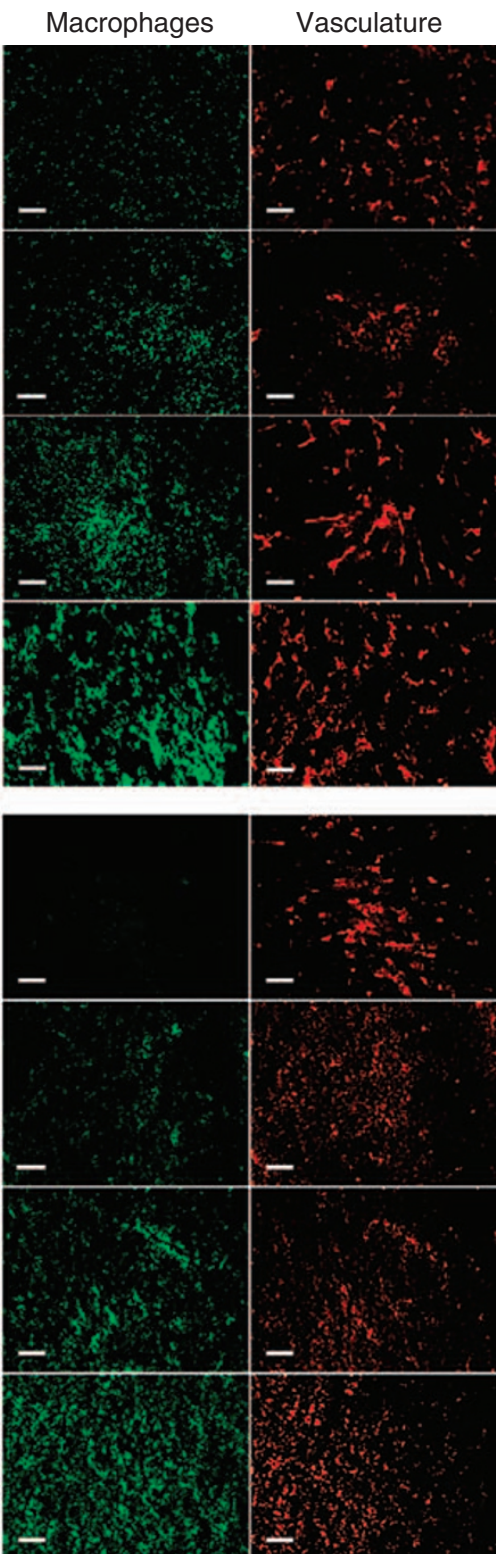

Figure 3 Immunofluorescence analysis of tumour-infiltrating immune cells and of microvascular density in the subcutaneous (A) and intracranial (B) glioblastoma models, $24 \mathrm{~h}$ after the third injection of therapeutic agents. The FI6-IL2 + temozolomide treatment groups show the largest increase in the infiltration of leukocytes and in particular of natural killer cells and macrophages (serial tissue sections). Scale bars indicate $100 \mu$ m.

subcutaneous model, but all mice were killed on day 25 from the start of therapy to allow a comparative evaluation of tumour burden for the four treatment groups. This time point was chosen as the end of the experiment (i.e., after killing all mice), as the first animal in the control group started to show signs of neurological damage. Mice of the combination therapy (F16IL2 + temozolomide) exhibited the strongest therapeutic benefit, with an average tumour volume of $14 \mathrm{~mm}^{3}$, compared with those of temozolomide alone $\left(33.5 \mathrm{~mm}^{3}\right)$, F16-IL2 alone $\left(36.8 \mathrm{~mm}^{3}\right)$, and the control group $\left(52 \mathrm{~mm}^{3}\right)$. Pairwise comparisons between the combination therapy group and temozolomide alone $(P=0.009)$, F16-IL2 alone $(P=0.001)$, and the control group $(P<0.001)$ were calculated using the two-tailed Student's $t$-test and showed significant results (Figure 2B). No signs of distress were observed in the animals during the entire treatment period.

We performed a further therapy experiment with intracranial glioblastoma-bearing mice to better evaluate the therapeutic benefit of F16-IL2 plus temozolomide on a survival basis. Four groups of mice were treated with the same doses and schedule as for the previous studies and were killed at the first appearance of neurological damage from tumour growth or on detection of any treatment-related toxicities. The Kaplan-Meier survival curve confirms the higher therapeutic benefit for the F16-IL2 plus temozolomide combination group (Figure 2C), with no augmented toxicity (Supplementary Figure 2B). Comparisons of the F16-IL2 plus temozolomide group with the other therapeutic groups were performed with the log-rank test and showed significant results (combo vs TMZ: $P<0.002$; combo vs F16-IL2: $P<0.002$; combo vs control: $P<0.0001)$.

Microscopic analysis of effector cell infiltration in subcutaneous and intracranial glioblastoma xenografts, and in normal tissues following treatment

To assess the infiltration of immune cells into tumours and in normal organs following treatment, subcutaneous and intracranial 
U87MG human glioblastoma-bearing mice were obtained after three drug administrations, and tumour, liver, and kidney sections were analysed by immunofluorescence. Figure 3 shows representative tumour sections of subcutaneous (A) and intracranial (B) glioblastoma xenografts, stained with antibodies anti-CD45 (a leukocyte-specific marker), anti-asialo GM1 (specific to NK cells), and anti-F4/80 (which recognises macrophages). Vascular structures were costained using an anti-CD31 antibody. The largest increase in infiltration of NK cells and macrophages was observed in combination F16-IL2 plus temozolomide-treated tumours in both subcutaneous and intracranial models (quantification in Supplementary Figure 3), whereas leukocytes were not detected in liver and kidneys of the same animals (Supplementary Figure 4). Pairwise comparisons of the immune cell infiltration into tumours (combo $v s$ the other treatments) were calculated using the two-tailed Student's $t$-test and showed significant results $(P<0.005)$.

\section{Ex vivo detection of the F16-IL2 fusion protein in subcutaneous and intracranial glioblastoma xenografts following treatment}

We performed an ex vivo localisation of the F16-IL2 fusion protein in subcutaneous and intracranial glioblastoma xenografts collected from BALB/c nude mice, which were obtained after three drug administrations of F16-IL2 or the combination of F16-IL2 and temozolomide. The staining for human IL-2 revealed a selective and comparable accumulation of the F16-IL2 immunocytokine around tumour vascular structures in both subcutaneous (A) and intracranial (B) xenografts (Figure 4).

\section{Microscopic analysis of apoptosis and proliferation in subcutaneous glioblastoma xenografts following treatment}

The influence of the different treatments on apoptosis and proliferation in subcutaneous glioblastoma mice was evaluated by immunofluorescence. Figure 5 shows a clear increase in apoptosis and a complete suppression of proliferation in the combination F16-IL2 plus temozolomide treatment group (quantification in Supplementary Figure 6). All pairwise comparisons between the combination and other therapeutic groups showed significant results using the two-tailed Student's $t$-test (apoptosis in combo $v s$ all other treatments: $P<0.001$; proliferation in combo vs placebo: $P<0.0001$, combo vs F16-IL2: $P<0.009$, combo vs TMZ: $P<0.02)$.

\section{DISCUSSION}

In this article, we have reported on the therapeutic performance of immunocytokine F16-IL2 and of temozolomide, alone and in combination, in subcutaneous and intracranial xenografts of U87MG human glioblastoma.

For both subcutaneous and intracranial U87MG xenografted mice, the combination of F16-IL2 with temozolomide gave the best therapeutic results without additional toxicity, compared with the drugs as single agents (Supplementary Figure 2). In the case of subcutaneous glioblastoma, F16-IL2 potentiated the action of temozolomide, leading to complete tumour eradication in all mice 40 days after beginning the treatment, and to the total remission of animals, which remained tumour free for over 160 days (Figure $2 \mathrm{~A}$ ). In addition, in the intracranial model, the combination treatment was more efficacious, resulting in a $73 \%$ decrease in tumour volume 25 days after the start of therapy (Figure $2 \mathrm{~B}$ ), as well as in a longer survival of the animals (Figure 2C).

In both subcutaneous and intracranial xenografts, immunocytokine F16-IL2 promoted the recruitment of immune effector cells into glioblastoma lesions (Figure 3 and Supplementary Figure 3),

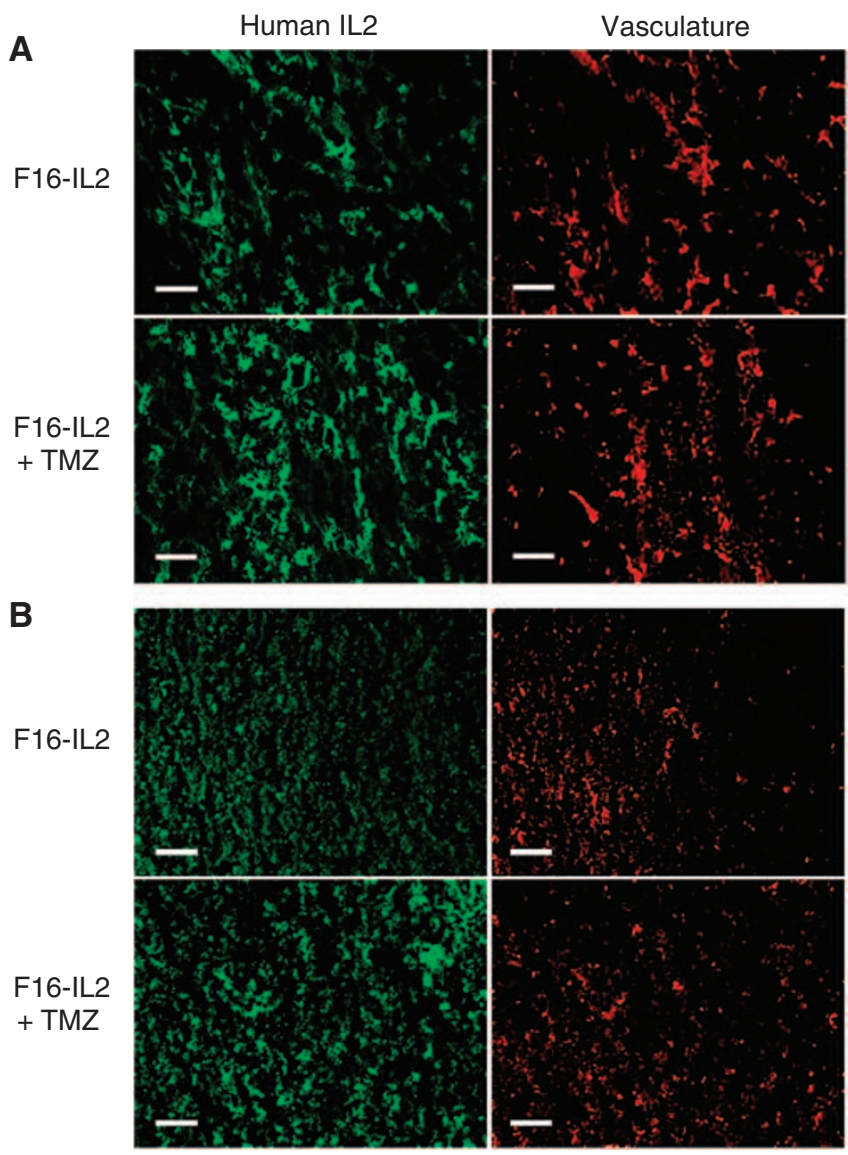

Figure 4 Immunofluorescence analysis of Fl6-IL2 fusion protein localisation in subcutaneous (A) and intracranial (B) glioblastoma xenografts, $24 \mathrm{~h}$ after the third injection of therapeutic agents (serial tissue sections). Scale bars indicate $100 \mu \mathrm{m}$.

in analogy to that previously observed in other immunocytokine therapies of mice with solid and haematological malignancies (Carnemolla et al, 2002; Halin et al, 2002, 2003; Mårlind et al, 2008; Schliemann et al, 2009). The infiltration of leukocytes was not observed in normal organs from the same mice, thus excluding a nonspecific inflammation caused by F16-IL2 (Supplementary Figure 4). The selective accumulation of F16-IL2 around tumour vascular structures in both subcutaneous and intracranial xenografts (Figure 4), the focal recruitment of immune effector cells (Figure 3), and the therapeutic effect on glioblastoma tumours of the F16-IL2 plus temozolomide combination therapy (Figure 2) support the anticancer role of effector cells stimulated by the immunocytokine.

Our group has previously shown that, surprisingly, the therapeutic effect of IL2-based immunocytokines against murine tumours is identical in immunocompetent and immunocompromised mice, and that NK cells are mainly responsible for the therapeutic action (Carnemolla et al, 2002; Halin et al, 2003; Ebbinghaus et al, 2005). By contrast, immunocytokines based on other cytokines (e.g., tumor necrosis factor, IL12, interferon- $\gamma$, IL15, and granulocyte macrophage colony-stimulating factor) exhibit a clear dependence on $\mathrm{T}$ cells (Borsi et al, 2003; Halin et al, 2003; Ebbinghaus et al, 2005; Kaspar et al, 2007). To document further possible mechanisms for the antitumour activity of the immunosuppressive reagent temozolomide in association with the immunostimulatory immunocytokine F16-IL2, we have studied apoptosis and cell proliferation in glioblastoma xenografts after three doses of the four treatments: combination of F16-IL2 


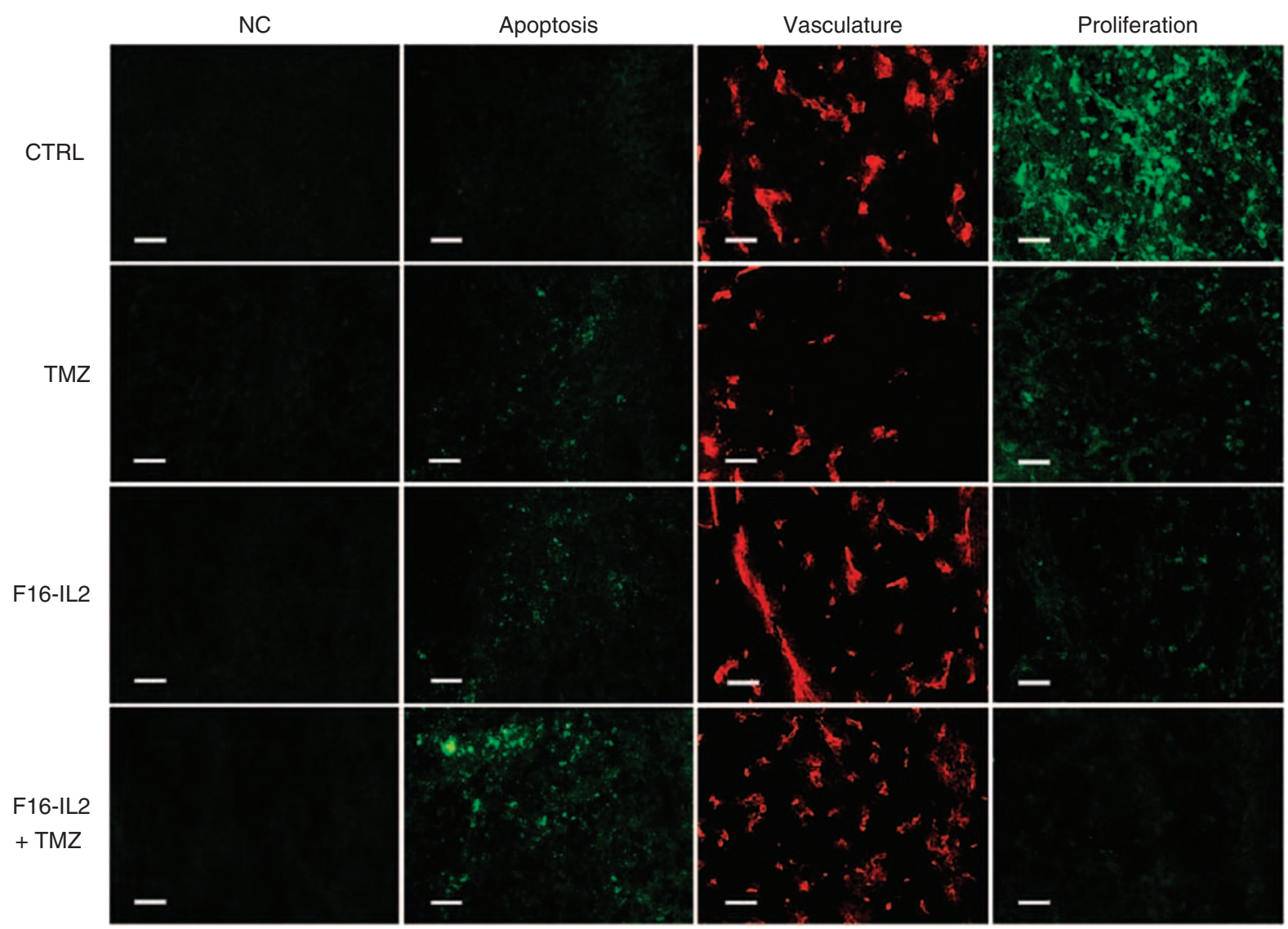

Figure 5 Immunofluorescence analysis of apoptosis and proliferation in subcutaneous glioblastoma xenografts, $24 \mathrm{~h}$ after the third injection of therapeutic agents. Results show a clear increase in apoptosis and the complete suppression of proliferation in the combination FI6-IL2 + temozolomide treatment group. Scale bars indicate $50 \mu \mathrm{m}$

with temozolomide, F16-IL2 alone, temozolomide alone, and saline $10 \%$ DMSO. Results show a clear increase in apoptosis and complete suppression of proliferation in the combination treatment group, thus supporting a cytostatic plus cytotoxic explanation of therapeutic efficacy (Figure 5 and Supplementary Figure 6).

In our study, F16-IL2 seems to be more effective as a single agent in the intracranial model, whereas the combination of F16-IL2 with temozolomide shows a higher efficacy in the subcutaneous model (Figure 2). We have conducted two independent therapy experiments with the intracranial model (Figure 2B and $\mathrm{C}$ ), which have confirmed both the therapeutic activity of F16-IL2 on its own and the additive therapeutic benefit observed in combination with temozolomide. There are a number of reasons why the same tumour cells (U87MG) may respond differently to therapy when implanted subcutaneously or orthotopically (in this case, intracranially). One first cause may be that the subcutaneous therapy study started when tumour masses were rather big $\left(300 \mathrm{~mm}^{3}\right.$; Figure $\left.2 \mathrm{~A}\right)$. In the intracranial study, no magnetic resonance imaging monitoring of lesion size at different time points was possible, but control experiments with the same tumour model suggest that lesions of $\sim 1-2 \mathrm{~mm}^{3}$ were present at day 12 from tumour cell implantation (when our therapy started). Moreover, we have observed in other mouse models of malignancies (melanoma, lymphoma, neuroblastoma, breast, and kidney cancer) that IL2-based immunocytokines may show a minimal therapeutic activity on their own, but strongly synergise with other therapeutic regimens, leading to complete tumour eradication (Schliemann et al, 2009; Balza et al, 2010; Frey et al, 2010; Giavazzi et al, manuscript in preparation). In other studies,
IL2-based immunocytokines showed a very potent therapeutic activity even when used as a single agent (Carnemolla et al, 2002; Menrad and Menssen, 2005; Mårlind et al, 2008). Finally, different therapeutic activities in subcutaneous and orthotopic models of glioblastoma have previously been reported by other groups (Friedman et al, 1995; Blouw et al, 2003; Graf et al, 2003; Yamini et al, 2007).

Two IL2-based immunocytokines (L19-IL2 and F16-IL2) are currently being investigated in phase I and phase II clinical trials in patients with cancer (Neri and Bicknell, 2005). These fully human immunocytokines can be studied in immunocompetent mouse models of cancer only in an acute setting, as they become immunogenic after a few injections (Carnemolla et al, 2002). Furthermore, although L19 reacts with equal affinity with its cognate human and murine antigens (Pini et al, 1998; Fattorusso et al, 1999), F16 recognises only human and monkey antigens (but not the rodent counterpart; Brack et al, 2006; Mårlind et al, 2008), thereby avoiding the therapy experiment in a syngeneic tumour model. The predictable effect of IL2-based immunocytokines in immunocompetent patients would be broader and stronger in tumour suppression, because of the involvement of T-cell and B-cell activation. With regard to the role of the blood-brain barrier in brain tumours, we have documented that the tumourtargeting ability of immunocytokine F16-IL2 is comparable in subcutaneous and intracranial mouse xenografts (Figure 4).

The results of this preclinical therapy study may justify the clinical evaluation of F16-IL2 in combination with temozolomide for the treatment of human glioblastoma. F16-IL2 has exhibited an excellent safety profile in cynomolgus monkeys and is currently 
being studied in two phase Ib clinical trials, in combination with doxorubicin (breast and ovarian cancer) or in combination with paclitaxel (breast and lung cancer).

\section{ACKNOWLEDGEMENTS}

We thank Dr Daniela Marino, Dr Sarah Wulhfard, Nadine Pasche, and Dr Alessandra Villa for their help with paraffin-embedded tissues (DM), with the TUNEL assay (SW, NP), and with the ex vivo analysis of F16-IL2 (AV). Financial contributions from the Swiss National Science Foundation to Dario Neri and Marta
Pedretti (Marie-Heim Vögtlin bursary no PMCDB-118729), from the ETH Zürich, the Swiss Cancer League, the SwissBridge Foundation, and the Stammbach Foundation to Dario Neri, Jessica Mårlind, and Marta Pedretti, from the AIRC (Associazione Italiana Ricerca sul Cancro) and the Italo Monzino Foundation to Lorenzo Bello, and from the European Union projects STROMA, ADAMANT, and IMMUNO-PDT to all authors of the article are gratefully acknowledged.

Supplementary Information accompanies the paper on British Journal of Cancer website (http://www.nature.com/bjc)

\section{REFERENCES}

Adams GP, Weiner LM (2005) Monoclonal antibody therapy of cancer. Nat Biotechnol 23: 1147-1157

Albertsson PA, Basse PH, Hokland M, Goldfarb RH, Nagelkerke JF, Nannmark U, Kuppen PJ (2003) NK cells and the tumour microenvironment: implications for NK-cell function and anti-tumour activity. Trends Immunol 24: 603-609

Balza E, Carnemolla B, Mortara L, Castellani P, Soncini D, Accolla RS, Borsi L (2010) Therapy-induced antitumor vaccination in neuroblastomas by the combined targeting of IL-2 and TNFalpha. Int J Cancer 127: $101-110$

Bello L, Lucini V, Costa F, Pluderi M, Giussani C, Acerbi F, Carrabba G, Pannacci M, Caronzolo D, Grosso S, Shinkaruk S, Colleoni F, Canron X, Tomei G, Deleris G, Bikfalvi A (2004) Combinatorial administration of molecules that simultaneously inhibit angiogenesis and invasion leads to increased therapeutic efficacy in mouse models of malignant glioma. Clin Cancer Res 10: 4527-4537

Berndorff D, Borkowski S, Moosmayer D, Viti F, Müller-Tiemann B, Sieger S, Friebe M, Hilger CS, Zardi L, Neri D, Dinkelborg LM (2006) Imaging of tumor angiogenesis using $99 \mathrm{mTc}$-labeled human recombinant anti-ED-B fibronectin antibody fragments. J Nucl Med 47: $1707-1716$

Birchler M, Viti F, Zardi L, Spiess B, Neri D (1999) Selective targeting and photocoagulation of ocular angiogenesis mediated by a phage-derived human antibody fragment. Nat Biotechnol 17: 984-988

Blouw B, Song H, Tihan T, Bosze J, Ferrara N, Gerber HP, Johnson RS, Bergers G (2003) The hypoxic response of tumors is dependent on their microenvironment. Cancer Cell 4: 133-146

Borsi L, Balza E, Bestagno M, Castellani P, Carnemolla B, Biro A, Leprini A, Sepulveda J, Burrone O, Neri D, Zardi L (2002) Selective targeting of tumoral vasculature: comparison of different formats of an antibody (L19) to the ED-B domain of fibronectin. Int J Cancer 102: 75-85

Borsi L, Balza E, Carnemolla B, Sassi F, Castellani P, Berndt A, Kosmehl H, Biro A, Siri A, Orecchia P, Grassi J, Neri D, Zardi L (2003) Selective targeted delivery of TNFalpha to tumor blood vessels. Blood 102: $4384-4392$

Bosslet K, Straub R, Blumrich M, Czech J, Gerken M, Sperker B, Kroemer HK, Gesson JP, Koch M, Monneret C (1998) Elucidation of the mechanism enabling tumor selective prodrug monotherapy. Cancer Res 58: $1195-1201$

Brack SS, Silacci M, Birchler M, Neri D (2006) Tumor-targeting properties of novel antibodies specific to the large isoform of tenascin-C. Clin Cancer Res 12: 3200-3208

Burnet NG, Jefferies SJ, Benson RJ, Hunt DP, Treasure FP (2005) Years of life lost (YLL) from cancer is an important measure of population burden and should be considered when allocating research funds. Br J Cancer 92: 241 - 245

Carnemolla B, Borsi L, Balza E, Castellani P, Meazza R, Berndt A, Ferrini S, Kosmehl H, Neri D, Zardi L (2002) Enhancement of the antitumor properties of interleukin-2 by its targeted delivery to the tumor blood vessel extracellular matrix. Blood 99: 1659-1665

Carter PJ (2006) Potent antibody therapeutics by design. Nat Rev Immunol 6: $343-357$

Castellani P, Borsi L, Carnemolla B, Biro A, Dorcaratto A, Viale GL, Neri D, Zardi L (2002) Differentiation between high- and low-grade astrocytoma using a human recombinant antibody to the extra domain-B of fibronectin. Am J Pathol 161: 1695-1700

Castellani P, Viale G, Dorcaratto A, Nicolo G, Kaczmarek J, Querze G, Zardi L (1994) The fibronectin isoform containing the ED-B oncofetal domain: a marker of angiogenesis. Int J Cancer 59: 612-618

CBTRUS Statistical report (2006) Primary brain tumors in the United States, 1998-2002. Central Brain Tumor Registry of the United States (CBTRUS): Chicago

Chakravarti A, Erkkinen MG, Nestler U, Stupp R, Mehta M, Aldape K, Gilbert MR, Black PM, Loeffler JS (2006) Temozolomide-mediated radiation enhancement in glioblastoma: a report on underlying mechanisms. Clin Cancer Res 12: $4738-4746$

Dunne J, Lynch S, O'Farrelly C, Todryk S, Hegarty JE, Feighery C, Doherty DG (2001) Selective expansion and partial activation of human NK cells and NK receptor-positive T cells by IL-2 and IL-15. J Immunol 167: $3129-3138$

Ebbinghaus C, Ronca R, Kaspar M, Grabulovski D, Berndt A, Kosmehl H, Zardi L, Neri D (2005) Engineered vascular-targeting antibody-interferon-gamma fusion protein for cancer therapy. Int $J$ Cancer 116: 304-313

Fattorusso R, Pellecchia M, Viti F, Neri P, Neri D, Wüthrich K (1999) NMR structure of the human oncofoetal fibronectin ED-B domain, a specific marker for angiogenesis. Structure 7: $381-390$

Ferlay J, Bray F, Pisani P, Parkin DM (2000) Globocan 2000: Cancer Incidence, Mortality, and Prevalence Worldwide. IARC Press: Lyon

Frey K, Schliemann C, Schwager K, Giavazzi R, Johannsen M, Neri D (2010) The immunocytokine F8-IL2 improves the therapeutic performance of sunitinib in a mouse model of renal cell carcinoma. $J$ Urol (in press)

Friedman HS, Dolan ME, Pegg AE, Marcelli S, Keir S, Catino JJ, Bigner DD, Schold Jr SC (1995) Activity of temozolomide in the treatment of central nervous system tumor xenografts. Cancer Res 55: 2853-2857

Friedman HS, Kerby T, Calvert H (2000) Temozolomide and treatment of malignant glioma. Clin Cancer Res 6: 2585-2597

Graf MR, Prins RM, Poulsen GA, Merchant RE (2003) Contrasting effects of interleukin-2 secretion by rat glioma cells contingent upon anatomical location: accelerated tumorigenesis in the central nervous system and complete rejection in the periphery. $J$ Neuroimmunol 140: 49-60

Halin C, Gafner V, Villani ME, Borsi L, Berndt A, Kosmehl H, Zardi L, Neri D (2003) Synergistic therapeutic effects of a tumor targeting antibody fragment, fused to interleukin 12 and to tumor necrosis factor alpha. Cancer Res 63: 3202-3210

Halin C, Rondini S, Nilsson F, Berndt A, Kosmehl H, Zardi L, Neri D (2002) Enhancement of the antitumor activity of interleukin-12 by targeted delivery to neovasculature. Nat Biotechnol 20: 264-269

Kaspar M, Trachsel E, Neri D (2007) The antibody-mediated targeted delivery of interleukin-15 and GM-CSF to the tumor neovasculature inhibits tumor growth and metastasis. Cancer Res 67: 4940-4948

Kleihues P, Cavenee WK (2000) WHO, Pathology and Genetics of Tumours of the Nervous System. IARC Press: Lyon

Mårlind $\mathrm{J}$, Kaspar $\mathrm{M}$, Trachsel $\mathrm{E}$, Sommavilla $\mathrm{R}$, Hindle $\mathrm{S}$, Bacci $\mathrm{C}$, Giovannoni L, Neri D (2008) Antibody-mediated delivery of interleukin2 to the stroma of breast cancer strongly enhances the potency of chemotherapy. Clin Cancer Res 14: 6515-6524

Menrad A, Menssen HD (2005) ED-B fibronectin as a target for antibody-based cancer treatments. Expert Opin Ther Targets 9: 491-500

Neri D, Bicknell R (2005) Tumour vascular targeting. Nat Rev Cancer 5: $436-446$ 
Newlands ES, Stevens MFG, Wedge SR, Wheelhouse RT, Brock C (1997) Temozolomide: A review of its discovery, chemical properties, preclinical development and clinical trials. Cancer Treat Rev 23: 35-61

Ohgaki H, Dessen P, Jourde B, Horstmann S, Nishikawa T, Di Patre PL, Burkhard C, Schüler D, Probst-Hensch NM, Maiorka PC, Baeza N, Pisani P, Yonekawa Y, Yasargil MG, Lutolf UM, Kleihues P (2004) Genetic pathways to glioblastoma: a population-based study. Cancer Res 64: $6892-6899$

Paganelli G, Bartolomei M, Grana C, Ferrari M, Rocca P, Chinol M (2006) Radioimmunotherapy of brain tumor. Neurol Res 28: 518-522

Parsons DW, Jones S, Zhang XS, Lin JC, Leary RJ, Angenendt P, Mankoo P, Carter H, Siu IM, Gallia GL, Olivi A, McLendon R, Rasheed BA, Keir S, Nikolskaya T, Nikolsky Y, Busam DA, Tekleab H, Diaz LA, Hartigan J, Smith DR, Strausberg RL, Marie SKN, Shinjo SMO, Yan H, Riggins GJ, Bigner DD, Karchin R, Papadopoulos N, Parmigiani G, Vogelstein B, Velculescu VE, Kinzler KW (2008) An integrated genomic analysis of human glioblastoma multiforme. Science 321: 1807-1812

Pedretti M, Soltermann A, Arni S, Weder W, Neri D, Hillinger S (2009) Comparative immunohistochemistry of L19 and F16 in non-small cell lung cancer and mesothelioma: two human antibodies investigated in clinical trials in patients with cancer. Lung Cancer 64: 28-33

Pini A, Viti F, Santucci A, Carnemolla B, Zardi L, Neri P, Neri D (1998) Design and use of a phage display library. Human antibodies with subnanomolar affinity against a marker of angiogenesis eluted from a two-dimensional gel. J Biol Chem 273: 21769-21776

Reagan-Shaw S, Nihal M, Ahmad N (2008) Dose translation from animal to human studies revisited. FASEB Journal 22: 659-661

Reisfeld RA, Gillies SD (1996) Antibody-interleukin 2 fusion proteins: a new approach to cancer therapy. J Clin Lab Anal 10: 160-166

Riva P, Franceschi G, Riva N, Casi M, Santimaria M, Adamo M (2000) Role of nuclear medicine in the treatment of malignant gliomas: the locoregional radioimmunotherapy approach. Eur J Nucl Med 27: $601-609$

Santimaria M, Moscatelli G, Viale GL, Giovannoni L, Neri G, Viti F, Leprini A, Borsi L, Castellani P, Zardi L, Neri D, Riva P (2003) Immunoscintigraphic detection of the ED-B domain of fibronectin, a marker of angiogenesis, in patients with cancer. Clin Cancer Res 9: 571-579

Schliemann C, Neri D (2007) Antibody-based targeting of the tumor vasculature. Biochim Biophys Acta Rev Cancer 1776: 175-192

Schliemann C, Palumbo A, Zuberbühler K, Villa A, Kaspar M, Trachsel E, Klapper W, Menssen HD, Neri D (2009) Complete eradication of human B-cell lymphoma xenografts using rituximab in combination with the immunocytokine L19-IL2. Blood 113: 2275-2283

Schrama D, Reisfeld RA, Becker JC (2006) Antibody targeted drugs as cancer therapeutics. Nat Rev Drug Discov 5: 147-159

Spaeth N, Wyss MT, Pahnke J, Biollaz G, Trachsel E, Drandarov K, Treyer V, Weber B, Neri D, Buck A (2006) Radioimmunotherapy targeting the extra domain B of fibronectin in C6 rat gliomas: a preliminary study about the therapeutic efficacy of iodine-131-labeled SIP(L19). Nucl Med Biol 33: $661-666$
Stupp R, Gander M, Leyvraz S, Newlands E (2001) Current and future developments in the use of temozolomide for the treatment of brain tumours. Lancet Oncol 2: $552-560$

Stupp R, Mason WP, van den Bent MJ, Weller M, Fisher B, Taphoorn MJB, Belanger K, Brandes AA, Marosi C, Bogdahn U, Curschmann J, Janzer RC, Ludwin SK, Gorlia T, Allgeier A, Lacombe D, Cairncross JG, Eisenhauer E, Mirimanoff RO, Van Den Weyngaert D, Kaendler S, Krauseneck P, Vinolas N, Villa S, Wurm RE, Maillot MHB, Spagnolli F, Kantor G, Malhaire JP, Renard L, De Witte O, Scandolaro L, Vecht CJ, Maingon P, Lutterbach J, Kobierska A, Bolla M, Souchon R, Mitine C, Tzuk-Shina T, Kuten A, Haferkamp G, de Greve J, Priou F, Menten J, Rutten I, Clavere P, Malmstrom A, Jancar B, Newlands E, Pigott K, Twijnstra A, Chinot O, Reni M, Boiardi A, Fabbro M, Campone M, Bozzino J, Frenay M, Gijtenbeek J, Brandes AA, Delattre JY, Bogdahn U, De Paula U, van den Bent MJ, Hanzen C, Pavanato G, Schraub S, Pfeffer R, Soffietti R, Weller M, Kortmann RD, Taphoorn M, Torrecilla JL, Marosi C, Grisold W, Huget P, Forsyth P, Fulton D, Kirby S, Wong R, Fenton D, Fisher B, Cairncross G, Whitlock P, Belanger K, BurdetteRadoux S, Gertler S, Saunders S, Laing K, Siddiqui J, Martin LA, Gulavita S, Perry J, Mason W, Thiessen B, Pai H, Alam ZY, Eisenstat D, Mingrone W, Hofer S, Pesce G, Curschmann J, Dietrich PY, Stupp R, Mirimanoff RO, Thum P, Baumert B, Ryan G, Br EORTC (2005) Radiotherapy plus concomitant and adjuvant temozolomide for glioblastoma. $N$ Engl J Med 352: $987-996$

Thorpe PE (2004) Vascular targeting agents as cancer therapeutics. Clin Cancer Res 10: 415-427

Tijink BM, Neri D, Leemans CR, Budde M, Dinkelborg LM, Stigter-van Walsum M, Zardi L, van Dongen GA (2006) Radioimmunotherapy of head and neck cancer xenografts using 131I-labeled antibody L19-SIP for selective targeting of tumor vasculature. J $\mathrm{Nucl} \mathrm{Med} \mathrm{47:}$ $1127-1135$

Yamini B, Yu X, Pytel P, Galanopoulos N, Rawlani V, Veerapong J, Bickenbach K, Weichselbaum RR (2007) Adenovirally delivered Tumor Necrosis Factor- $\alpha$ improves the antiglioma efficacy of concomitant radiation and temozolomide therapy. Clin Cancer Res 13: $6217-6223$

Yung WKA, Albright RE, Olson J, Fredericks R, Fink K, Prados MD, Brada M, Spence A, Hohl RJ, Shapiro W, Glantz M, Greenberg H, Selker RG, Vick NA, Rampling R, Friedman H, Phillips P, Bruner J, Yue N, Osoba D, Zaknoen S, Levin VA (2000) A phase II study of temozolomide vs procarbazine in patients with glioblastoma multiforme at first relapse. Br J Cancer 83: 588-593

Zalutsky MR, Reardon DA, Akabani G, Coleman RE, Friedman AH, Friedman HS, McLendon RE, Wong TZ, Bigner DD (2008) Clinical experience with alpha-particle-emitting 211At: treatment of recurrent brain tumor patients with 211At-labeled chimeric antitenascin monoclonal antibody 81C6. J Nucl Med 49: 30-38

Zalutsky MR, Reardon DA, Pozzi OR, Vaidyanathan G, Bigner DD (2007) Targeted alpha-particle radiotherapy with 211At-labeled monoclonal antibodies. Nucl Med Biol 34: 779-785 